\title{
Capitalism and Society
}

Volume 3, Issue 3

Ned Phelps-The Economist: American

Economic Association Luncheon Speech

Honoring the 2006 Nobel Laureate in

Economics

Amartya Sen* 
The following speech was given at the American Economic Association Annual Meetings, New Orleans, January 5, 2008.

Whenever the latest recipient of the Nobel award in economics is announced in October, a huge sigh tends to go up across the academic world asserting the claims of others who did not get the prize but could very reasonably have been given the award. For a great many years Ned Phelps was one of the major sigh-recipients in those autumnal days in October, until one morning in 2006 Ned became the principal sigh-generator. Happily, along with the sighs, the announcements are greeted with jubilations by friends and admirers of the respective recipients, and since in the case of Ned Phelps, I belong to both the categories, the announcement gave me an occasion for double jubilation.

In fact, Ned could have got his prize for one of many different contributions. And this made me wonder, before I saw the awarding statement of the Royal Swedish Academy, which of the different grounds the Nobel committee had chosen to mention. I also remember recollecting then a nice cartoon I had seen many years ago - I think it was in the New Yorker - where a wife puts her Nobel-graced husband in his place by saying, "Tell me, darling, was it only that one time that you managed to get the Nobel?" I don't quite think that Viviana will need to resort to this form of elocution to stop Ned from getting too big for his boots (she knows many other ways of doing this!), but it is indeed true that Ned could have got the award more than just "that one time" had rules permitted this.

In the few minutes I have, let me choose to comment on a side of Ned's work - and indeed of his priorities in life - that has not received as much notice as it could have. This concerns not so much Ned's skill in doing his work - that of course is outstanding - but the motivation behind the work he chooses to do. Macroeconomics used to be an account of gigantic impersonal forces - national income, money supply, aggregate savings, and such - encountering each other in a mindless world. Long time ago, I once taught a basic macroeconomic course for graduate students - this was at Berkeley in 1965 - and I remember being constantly reminded of Matthew Arnold's chilling description in his poem "Dover Beach":

\footnotetext{
And we are here as on a darkling plain

Swept with confused alarms of struggle and flight,

Where ignorant armies clash by night.
}

I thought "ignorant armies clashing at night" was a rather apt description of what we can call "mindless macro-economics."

Well, since those days more than forty years ago, huge steps have been taken to make macro-economics "less mindless," giving human beings central roles in the understanding, expectation, assessment and choice that make the outcomes what they 
are. Ned's contributions in putting mind into macro-economic matter have, of course, been totally extraordinary. He has played a very big part in making sure that understandings and expectations in human decisions have their rightful place in macro-economics. Indeed, his "expectations-augmented Phillips curve" is an excellent example of such an integration.

All this has been much celebrated by now. But there is another question of much interest: why should we be so interested in these inanimate macro-economic objects in the first place? It is one thing to find out how inflation rates, employment levels, growth rates, etc. are determined, but quite another to assess how each of these objects are relevant to the reasons that make economics such an important subject for the lives of human beings. The micro-economic underpinnings of macro investigations give us only half the story: there is also the question of the human interests, including normative concerns, which lie - explicitly or by implicationbehind these investigations. Ned Phelps has constantly kept those motivations in view and been significantly guided by them in his choice of macro questions.

The fact that Ned is also quite an expert on the theory of justice has certainly helped-his early book Economic Justice (edited and published by him in 1973) played a pivotal role in making economists familiar with John Rawls's analyses of the demands of justice. But there is more here than Ned's mastery over two distinct fields; there is also the very important problem of the traverse from one to the other. Ned's sense of direction towards the quality and freedom of human lives is easily seen in his involvement with "rewarding work," with "participation and selfsupport," with "designing inclusion," and with other such concerns that often get left out in many otherwise-distinguished treatises on macro-economic analysis.

Even Ned's other writings outside macro-economics have often played that inter-linking role. For example, his paper in the American Economic Review in 1972, on how informational limitation and the cost of gathering additional information about individual members of a disadvantaged group can lead to what he calls a "statistical" strengthening of racism and sexism was indeed a hugely significant contribution to practical reason guided by a normative commitment to remove injustice in the world.

There has not been anyone quite like Ned Phelps in linking these diverse but interrelated commitments. I hope Ned the Economist goes on vigorously consulting Ned the Normative Theorist in his future works as well. He may have to be satisfied with getting the Nobel "only that one time," but we, the masses, can go on jubilating about Ned Phelps's work again and again. 


\section{REFERENCES}

Arnold, Matthew (1867), New Poems. London: Macmillan \& Co., 1867, 112-114. Phelps, Edmund S. (1972), "The Statistical Theory of Racism and Sexism." American Economic Review 62(4) 659-661 (reprinted in Alice Amsden, ed. 1980. The Economics of Women and Work. New York: Penguin).

Phelps, Edmund S. (1974), Economic Justice. Harmondsworth, England: Penguin. 